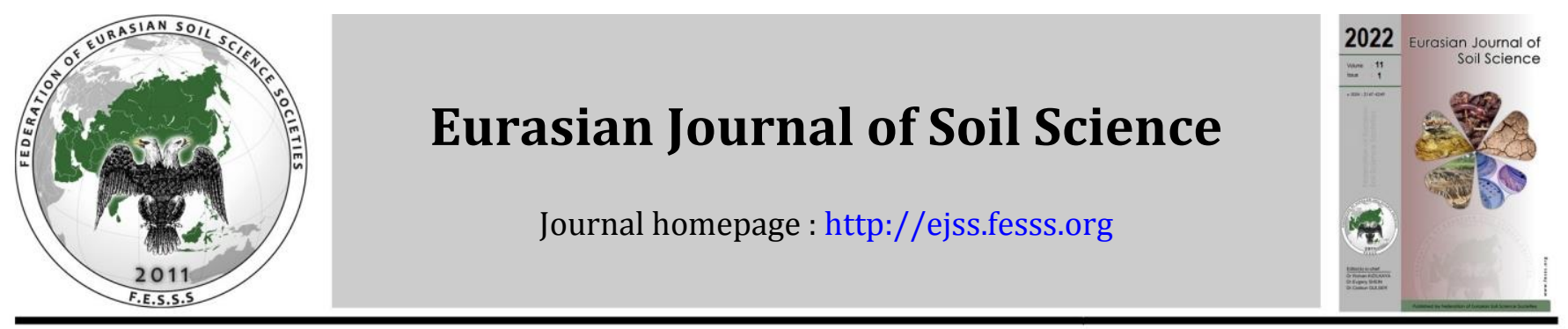

\title{
Morphophysiological response of young Frantoio olive tree under different fertilizer types in sierozem with surface drip irrigation
}

\author{
Nurgul Alimbekova a,*, Baisserik Issabekov b, Serik Orazbayev a, \\ Zhainagul Yertayeva ${ }^{a}$, Laura Yessengeldiyeva ${ }^{b}$ \\ a Kazakh National Agrarian Research University, 050010, Almaty, Kazakhstan \\ b M. Auezov South Kazakhstan State University, Shymkent, Kazakhstan
}

\section{Article Info}

Received : 21.05.2021

Accepted : 15.09.2021

Available online : 17.09 .2021

\section{Author(s)}
N. Alimbekova *
B. Issabekov
S. Orazbayev
Z. Yertayeva
L. Yessengeldiyeva

* Corresponding author

\begin{abstract}
The amount of yield and adaptation of a cultivar to a new environment is strongly related to nutrient uptake ability. This study was carried out during 2019, 2020 and 2021 seasons to investigate the effect of different forms of chemical compose 20.20.20 fertilization alone or incombination with other fertilizers on morphological plant parameters (number of leaves per shoot, stem length and stem thickness) and leaf nutrient contents (N, P, K and Mg) of young Frantoio olive tree grown in Turkestan region, South Kazakhstan. The study was conducted on 1 years old olive trees of Frantoio in sierozem, under surface drip irrigation, system and uniform in shape and received the common horticultural practices. It was determined that fertilizer treatments significantly influenced number of morphological plant parameters and leaf plant nutrients compared to control treatments at all seasons. Results revealed that all fertilizers as well as the combination between 20.20.20 and Biohumus treatment and/or Nitroammophos treatment significantly increased morphological plant parameters and nutrient contents of young Frantoio olive trees. It can be concluded that the variation in the nutrient uptake ability may be used as a criterion for adaptation of a variety to a new ecological environment.
\end{abstract}

Keywords: Olive tree, fertilizer, drip irrigation, soil, sierozem.

(C) 2022 Federation of Eurasian Soil Science Societies. All rights reserved

\section{Introduction}

The olive tree (Olea europaea L.) is an ancient, traditional crop in the Mediterranean Basin (Langgut et al., 2019; Arenas-Castro et al., 2020). It is believed that the olive tree originated in the Mediterranean region and has been cultivated since 4800 BC (Fraga et al., 2021). It originated in the eastern Mediterranean and was spread widely around southern Europe, northern Africa, and the Iberian Peninsula. More recently, it has been introduced to other continents including the Americas, South Africa, Australia and Asia (Connor, 2005). The world area of olive is around 9 Mha, with major production (95\% of 2.5 Mt oil) in 5 Mediterranean countries, Greece, Italy, Spain, Tunisia, and Turkey. Other continents, South America, South Africa, and Australia, are now becoming significant producers. The initial expansion around the Mediterranean moved the crop into comparable, although drier (southern) and colder (northern) environments. The present 'New World' expansion is taking olive into non-Mediterranean climates, e.g. subtropics in Australia and Argentina, where the response of the crop is yet to be studied in detail (Connor, 2005).

Olive is a drought-resistant plant. In general, the traditional olive orchards in Mediterranean areas are under rain-fed conditions without any form of irrigation (Sofo et al., 2008). However, in modern intensive

https://doi.org/10.18393/ejss.996621

http://ejss.fesss.org/10.18393/ejss.996621 
orchards, more trees are planted per hectare than are in traditional orchards, which leads to decreased water availability for individual olive trees at a specific area with a relatively stable amount of rainfall (Fernández and Moreno, 1999). As a consequence, olive growth, including vegetative growth (the basis for flowering and cropping in the next year), flower-bud formation, and fruit development, could be limited by water shortage (Masmoudi-Charfi and Mechlia, 2008; Gucci et al., 2009). Studies have shown that irrigation during summer and autumn in a Mediterranean climate is an effective way to increase olive productivity (Proietti and Antognozzi, 1996; Sanz-Cortes et al., 2015; Liu et al., 2019).

South Kazakhstan is mostly an arid and semi-arid, strongly continental climate, with hot summers and cold winters. Sierozems are brown desert soils that are located in Turkestan region of South Kazakhstan (Shokparova and Issanova, 2013; Beketova et al., 2017; Yertayeva et al., 2018). Sierozem soils are a valuable resource because of their extent and because they are fertile, but, sierozems have low soil organic matter content. Sierozems must be properly managed and protected for efficient and sustainable productivity. They have been researched in the past but mainly as a soil-geographic resource. Further study is needed to quantify and expand their value in production and assure environmental sustainability (Jalankuzov et al., 2013; Saparov, 2014). Some fertilizers including humus and/or humic acids are a ready-to-use live formulation of such beneficial microorganisms which on application to seed, root or soil, mobilize the availability of nutrients by their biological activity. They help build up the soil micro-flora and there by the soil health. Use of fertilizer including humus and/or humic acids are recommended for improving the soil fertility in sustainable farming.

In the main growing area in the Turkestan region, South Kazakhstan, there is almost no rainfall during summer. In recent years, most of the olive trees in Turkestan region have been planted, and drip irrigation has been applied in the modern intensive olive orchards to replace traditional flood irrigation. However, little is known about the effects on olive productivity of fertilization regimes with surface drip irrigation in South Kazakhstan. Therefore, a 3-year field study was conducted to gain a better understanding the effect of chemical fertilizers alone or in combination with other fertilizers including humus and/or humic acids on vegetative growth, leaf mineral contents of Frantoio olive trees grown in sierozem with surface drip irrigation in Turkestan region, South Kazakhstan.

\section{Material and Methods}

\section{Study Area}

The experiment was performed at Ordabasy district of the Turkestan region, South Kazakhstan (Figure 1). The experimental fields had been in new olive growing area of Turkestan region at 3 years (2019-2021). In this area, efforts are being made to create new olive plantations. This region is characterized by a semi-arid climate. Most of the precipitation occurred in June to September. The annual mean precipitation and mean temperature from the establishment of the experiment is shown in Figure 2.

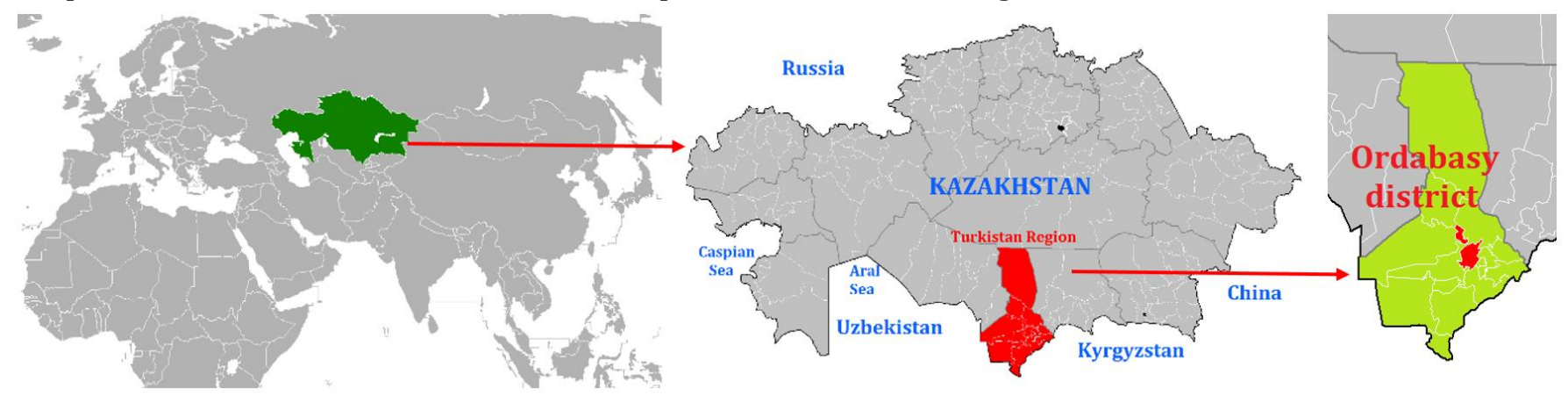

Figure 1. Study area

\section{Soil}

The main soil type, which is typical for the region, is sierozem soils. The sierozem soils are found in arid regions which characterized by a brownish-gray surface on a lighter layer based on a carbonate or hard-pan layer (USDA, 1999). Ordinary sierozems develop on loess-like loams and have fully developed profile with a rather noticeable division into genetic horizons. Sierozems are marked by good water-physiological properties, high biological activity, and adequate fertility; they produce high yields when irrigated. There are various subtypes: light, conventional (standard), dark, and northern (Saparov, 2014). The soil belongs to the general soil type of dark sierozem. The soil $\mathrm{pH}$ was 7,7 and organic matter content was $0.96 \%, \mathrm{NO}_{3}-\mathrm{N}$ was $5.4 \mathrm{mg} \mathrm{kg}^{-1}$, available phosphorus was $6.04 \mathrm{mg} \mathrm{kg}^{-1}$ and exchangeable potassium was $380 \mathrm{mg} \mathrm{kg}^{-1}$. 

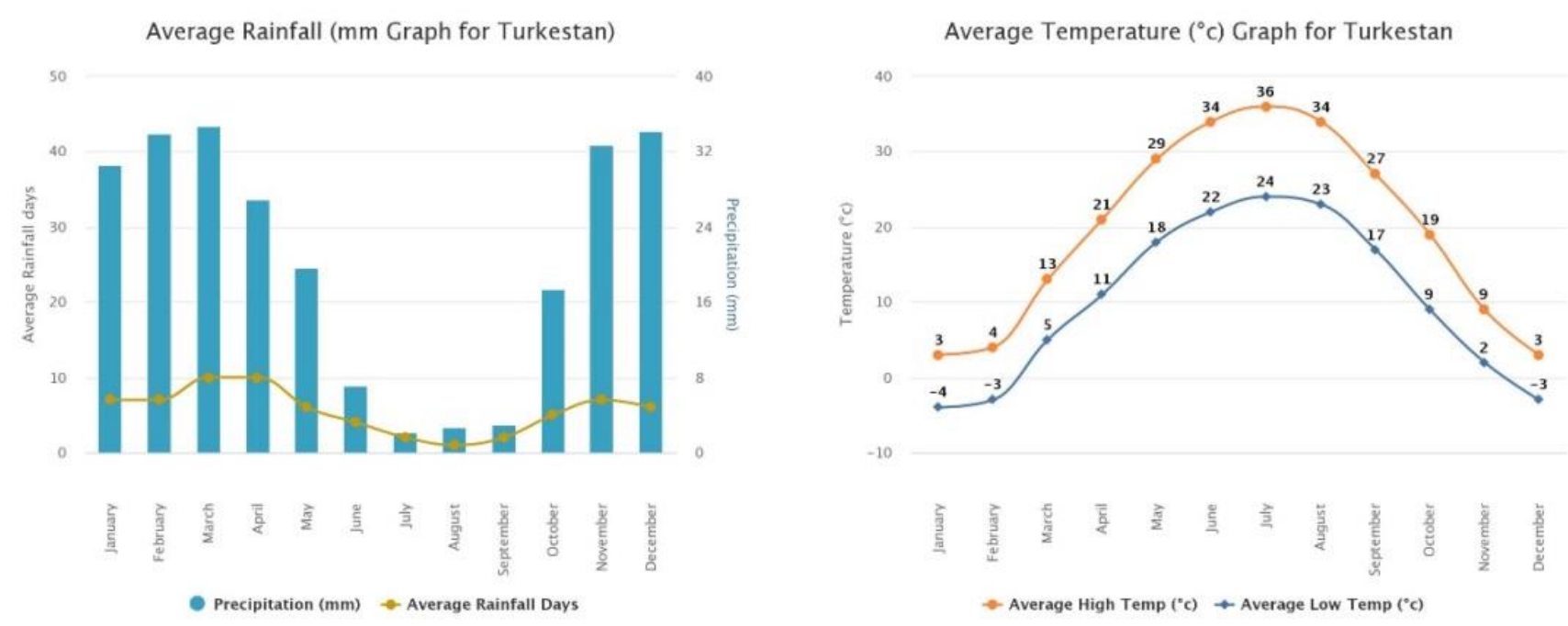

Figure 2. Monthly average temperature $\left({ }^{\circ} \mathrm{C}\right)$ and distribution of precipitation $(\mathrm{mm})$ of the experimental area.

\section{Olive (Olea europaea)}

Frantoio olive variety were sampled and which was introduced from Turkey as 1-year-old cuttings in 2019. Some general informations and agronomic properties of Frantoio olive variety is given below and Table 1.

Table 1. Some agronomic properties of Frantoio olive tree

\begin{tabular}{lc}
\hline Origin & Italy \\
Cold tolerance & Low \\
Self sterile Productivity & High \\
Start of bearing & Early \\
Ripening & Late \\
Oil content & High \\
\hline
\end{tabular}

Frantoio is a moderately vigorous tree with a spreading-drooping growth habit and medium-dense canopy. It is one of the main varieties in the classic Tuscan blend. Frantoio is highly and consistently productive, and very adaptable. It is quite cold sensitive, however, and can suffer frost damage while other varieties in the same orchard are unscathed. Frantoio is self fertile, but the yields increase with the presence of pollinizers. Pendolino is the most popular choice for a pollinizer, but Leccino and Maurino are suitable as well. Frantoio is popular world-wide, with significant acreage in Australia, Argentina and Chile.

\section{Fertilizers}

Five different fertilizer were used as treatments. Nutrient contents of fertilizers are given in Table 2 and all fertilizers used were in the form of wholly soluble.

Table 2. Nutrient content of the fertilizers used in the experiment

\begin{tabular}{lccccccc}
\hline Fertilizers & Humus, $\%$ & Humic acid, $\%$ & $\mathrm{~N}, \%$ & $\mathrm{P}_{2} \mathrm{O}_{5}, \%$ & $\mathrm{~K}_{2} \mathrm{O}, \%$ & $\mathrm{Ca}, \%$ & $\mathrm{Mg}, \%$ \\
\hline Compose fertilizer & - & - & 20 & 20 & 20 & 0,2 & 0,3 \\
Nitroammophos & - & - & 16 & 16 & 16 & 0,1 & 0,3 \\
Biohumus & 10 & - & 0.9 & 1.3 & 1.5 & 4.5 & 0.5 \\
Calcium Humate & - & 80 & 0.8 & 0.9 & 0.7 & 0.2 & 0.1 \\
Potassium humate & - & 80 & 0.5 & 0.8 & 0.6 & 0.2 & 0.5 \\
\hline
\end{tabular}

\section{Treatments and Experimental design}

A long term experiment was established at Ordabasy district of the Turkestan region, South Kazakhstan in April 2019 and the field trial was conducted during three consecutive seasons (2019, 2020 and 2021). The trees were evenly planted at three different planting density. These are i) $4.0 \mathrm{~m} \times 3.0 \mathrm{~m}$, ii) $4.0 \mathrm{~m} \times 2.0 \mathrm{~m}$, and iii) $4.0 \mathrm{~m} \times 1.5 \mathrm{~m}$. Two water-dripping lines were placed on the south and north sides along the trees, $30 \mathrm{~cm}$ away from trees. The drip lines ran east west, with a pipe diameter of $14 \mathrm{~mm}$ and emitter spacing of $30 \mathrm{~cm}$. The drip rate was $2 \mathrm{~L} \mathrm{~h}^{-1}$. Photographs from the experiment are given in Figure 3. 

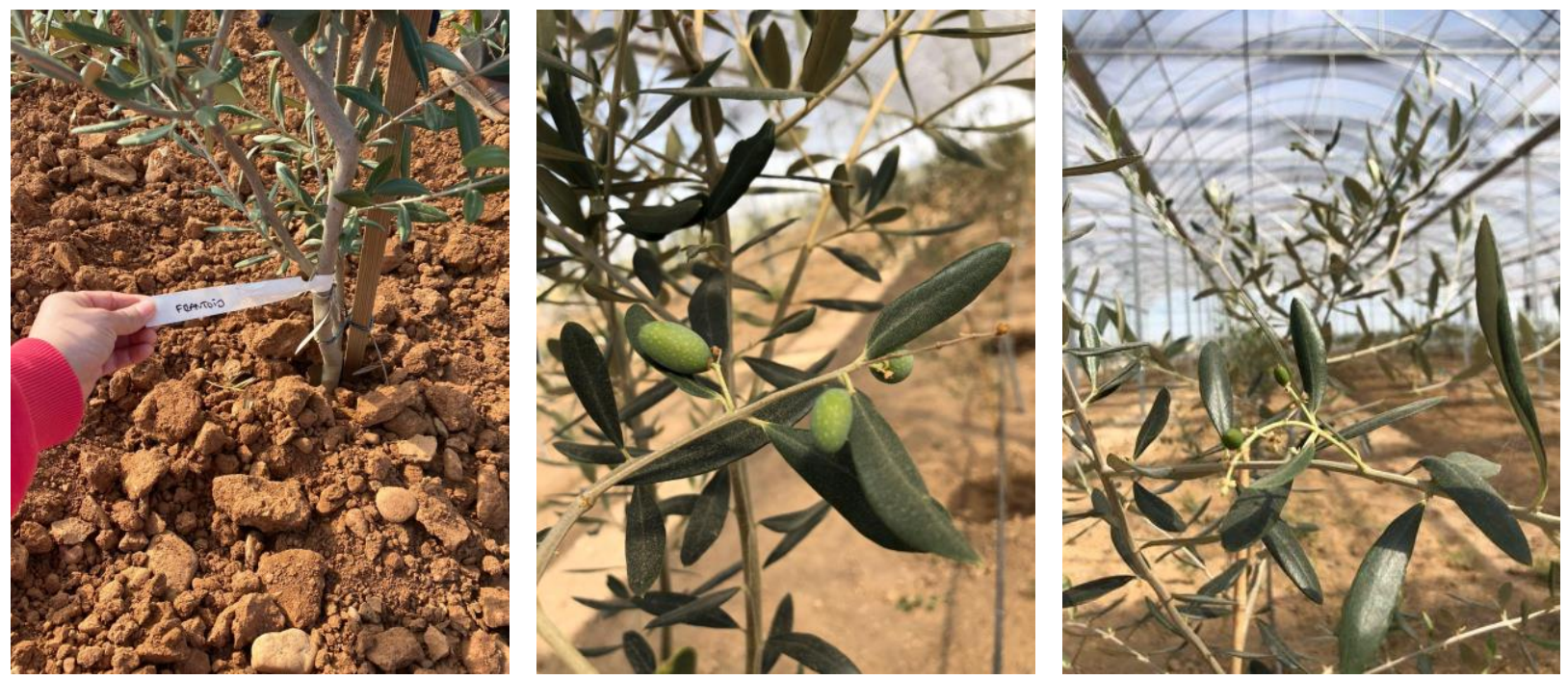

Figure 3. Photographs from the experiment

The experiment adopted a randomized block design with three different planting density and different fertilizer type and was performed with the following 15 treatments.

C01 : Control ; + 20.20.20 (3 kg/ton water in week) with Drip irrigation during April to September ; Planting density is $4 \mathrm{~m} \times 3 \mathrm{~m}$

CO2 : Control ; + 20.20.20 (3 kg/ton water in week) with Drip irrigation during April to September ; Planting density is $4 \mathrm{~m} \times 2 \mathrm{~m}$

C03 : Control ; +20.20 .20 (3 kg/ton water in week) with Drip irrigation during April to September ; Planting density is $4 \mathrm{~m} \times 1,5 \mathrm{~m}$

BH1 : Biohumus treatment (3kg /ton water in week) +20.20 .20 (3 kg/ton water in week) with Drip irrigation during April to September ; Planting density is $4 \mathrm{~m} \times 3 \mathrm{~m}$

BH2 : Biohumus treatment (3kg /ton water in week) +20.20 .20 (3 kg/ton water in week) with Drip irrigation during April to September ; Planting density is $4 \mathrm{~m} \times 2 \mathrm{~m}$

BH3 : Biohumus treatment (3kg /ton water in week) +20.20 .20 (3 kg/ton water in week) with Drip irrigation during April to September ; Planting density is $4 \mathrm{~m} \times 1,5 \mathrm{~m}$

CH1 : Calcium humate treatment $(0,5 \mathrm{lt} /$ ton water in week $)+20.20 .20(3 \mathrm{~kg} /$ ton water in week $)$ with Drip irrigation during April to September ; Planting density is $4 \mathrm{~m} \times 3 \mathrm{~m}$

CH2 : Calcium humate treatment $(0,5 \mathrm{lt} /$ ton water in week $)+20.20 .20(3 \mathrm{~kg} /$ ton water in week $)$ with Drip irrigation during April to September ; Planting density is $4 \mathrm{~m} \times 2 \mathrm{~m}$

CH3 : Calcium humate treatment $(0,5 \mathrm{lt} /$ ton water in week $)+20.20 .20(3 \mathrm{~kg} /$ ton water in week $)$ with Drip irrigation during April to September ; Planting density is $4 \mathrm{~m} \times 1,5 \mathrm{~m}$

PH1 : Potassium humate treatment $(0,5 \mathrm{lt} /$ ton water in week $)+20.20 .20$ (3 kg/ton water in week) with Drip irrigation during April to September ; Planting density is $4 \mathrm{~m} \times 3 \mathrm{~m}$

PH2 : Potassium humate treatment $(0,5 \mathrm{lt} /$ ton water in week $)+20.20 .20(3 \mathrm{~kg} /$ ton water in week $)$ with Drip irrigation during April to September ; Planting density is $4 \mathrm{~m} \times 2 \mathrm{~m}$

PH3 : Potassium humate treatment $(0,5 \mathrm{lt} /$ ton water in week $)+20.20 .20$ (3 kg/ton water in week) with Drip irrigation during April to September ; Planting density is $4 \mathrm{~m} \times 1,5 \mathrm{~m}$

NA1 : Nitroammophos treatment (2 lt /ton water in week) +20.20 .20 (3 kg/ton water in week) with Drip irrigation during April to September ; Planting density is $4 \mathrm{~m} \times 3 \mathrm{~m}$

NA2 : Nitroammophos treatment (2 lt /ton water in week) +20.20 .20 (3 kg/ton water in week) with Drip irrigation during April to September ; Planting density is $4 \mathrm{~m} \times 2 \mathrm{~m}$

NA3 : Nitroammophos treatment (2 lt /ton water in week) +20.20 .20 (3 kg/ton water in week) with Drip irrigation during April to September ; Planting density is $4 \mathrm{~m} \times 1.5 \mathrm{~m}$

\section{Observed parameters}

Four branches with flower buds and new apical shoots from the four directions (east, south, west, and north) in each sampling tree were labeled at the end of April for field survey, and counted in August. Observed morphological parameters in plants were number of leaves, stem length, stem thickness and leaf plate size. Nutrient concentration (N, P, K, Mg) in leaf. All parameters were measured according to Jones (2001). 


\section{Results and Discussion}

\section{Morphological plant parameters}

Morphological plant parameters such as the number of leaves per shoot, stem length and stem thickness of young Frantoio olive tree differed significantly due to different fertilization all season (Table 3). At all seasons, fertilizer treatments significantly influenced number of leaves per shoot, stem length and stem thickness compared to control treatments. On the contrary, it was determined that planting density did not affected morphological plant parameters of young Frantoio olive tree at all season and fertilization compared to control treatments.

Table 3. Effect of different types of fertilizers on Morphological plant parameters of young Frantoio olive tree

\begin{tabular}{|c|c|c|c|c|c|c|c|c|c|c|c|c|c|c|c|c|}
\hline \multirow{2}{*}{ Treatments } & \multicolumn{4}{|c|}{ Number of leaves per shoot } & \multicolumn{4}{|c|}{ Stem length, $\mathrm{cm}$} & \multicolumn{4}{|c|}{ Stem thickness, cm } & \multicolumn{4}{|c|}{ Leaf plate size, $\mathrm{cm}$} \\
\hline & 2019 & 2020 & 2021 & mean & 2019 & 2020 & 2021 & mean & 2019 & 2020 & 2021 & mean & 2019 & 2020 & 2021 & mean \\
\hline C01 & 2,5 & 3,8 & 32,0 & 12,8 & 30,2 & 45,0 & 51,4 & 42,2 & 0,5 & 1,25 & 2,1 & 1,3 & 0,5 & 1,2 & 2,4 & 1,4 \\
\hline $\mathrm{CO2}$ & 2,7 & 3,9 & 33,2 & 13,3 & 36,2 & 45,8 & 51,9 & 44,6 & 0,6 & 1,2 & 2,2 & 1,3 & 0,7 & 1,4 & 2,6 & 1,6 \\
\hline C03 & 2,6 & 3,8 & 34,1 & 13,5 & 36,0 & 45,5 & 51,7 & 44,4 & 0,7 & 1,0 & 2,4 & 1,4 & 0,8 & 1,3 & 2,5 & 1,5 \\
\hline BH1 & 4,7 & 8,4 & 36,8 & 16,6 & 36,4 & 48,2 & 54,6 & 46,4 & 0,9 & 1,6 & 2,7 & 1,7 & 1,8 & 1,7 & 4,2 & 2,6 \\
\hline BH2 & 6,2 & 9,2 & 37,2 & 17,5 & 35,8 & 48,7 & 54,8 & 46,4 & 1,2 & 1,7 & 3,2 & 2,0 & 1,9 & 1,9 & 5,2 & 3,0 \\
\hline BH3 & 6,1 & 9,0 & 37,0 & 17,4 & 35,6 & 48,5 & 54,7 & 46,3 & 1,5 & 1,5 & 3,0 & 2,0 & 1,6 & 1,6 & 5,0 & 2,7 \\
\hline CH1 & 4,2 & 8,0 & 41,0 & 17,7 & 35,0 & 48,3 & 54,2 & 45,8 & 0,6 & 1,4 & 2,6 & 1,5 & 1,4 & 1,4 & 4,9 & 2,6 \\
\hline $\mathrm{CH} 2$ & 4,8 & 8,4 & 42,3 & 18,5 & 35,6 & 48,6 & 53,7 & 46,0 & 0,7 & 1,6 & 2,8 & 1,7 & 1,6 & 1,6 & 5,1 & 2,8 \\
\hline PH1 & 4,0 & 10,2 & 39,2 & 17,8 & 34,4 & 48,0 & 52,3 & 44,9 & 0,5 & 1,5 & 2,8 & 1,6 & 1,2 & 1,5 & 2,9 & 1,9 \\
\hline PH2 & 4,9 & 10,5 & 39,8 & 18,4 & 34,7 & 48,4 & 52,7 & 45,3 & 0,6 & 1,7 & 2,6 & 1,6 & 1,3 & 1,6 & 3,1 & 2,0 \\
\hline PH3 & 4,6 & 10,2 & 39,6 & 18,1 & 34,5 & 48,2 & 52,5 & 45,1 & 0,5 & 1,6 & 2,7 & 1,6 & 1,0 & 1,4 & 3,0 & 1,8 \\
\hline NA1 & 5,0 & 7,5 & 35,6 & 16,0 & 35,6 & 49,5 & 54,5 & 46,5 & 0,9 & 1,7 & 3,0 & 1,9 & 1,7 & 1,9 & 4,7 & 2,8 \\
\hline NA2 & 5,8 & 7,8 & 35,9 & 16,5 & 35,7 & 49,7 & 54,8 & 46,7 & 1,2 & 1,9 & 3,1 & 2,1 & 1,9 & 2,0 & 5,2 & 3,0 \\
\hline NA3 & 5,5 & 7,4 & 35,6 & 16,2 & 35,5 & 49,6 & 54,4 & 46,5 & 1,1 & 1,8 & 3,0 & 2,0 & 1,8 & 1,8 & 5,0 & 2,9 \\
\hline Mean & 4,5 & 7,8 & 37,4 & 16,6 & 35,1 & 48,0 & 53,4 & 45,5 & 0,8 & 1,5 & 2,7 & 1,7 & 1,4 & 1,6 & 4,1 & 2,3 \\
\hline
\end{tabular}

Data presented in Table 3 indicate that, number of leaves per shoot, leaf plate size, was affected by conducted treatments in the three seasons. BH (Biohumus treatment) resulted in highest significantly number of leaves per shoot in first, PH (Potassium humate treatment) was in second and $\mathrm{CH}$ (Calcium humate treatment) was in third seasons respectivitly. On the other side, the lowest number of leaves per shoot was obtained from CO (Control) treatment since it was in the first, second and third seasons. In addition, leaf plate size was affected by different treatments in first, second and third seasons. BH and NA treatments resulted in the largest leaf plate size in the first, second and third seasons. On the other contrary the lowest leaf plate size was found in CO treatments all seasons. Research results showed that stem length and stem thickness was significantly affected with different fertilizer treatments (Table 3). BH treatments and NA treatments recorded the highest value in the all seasons. On the contrary, the lowest stem length and stem thickness was recorded under the CO treatments in all season. Similar results were obtained by Bilalis et al. (2015), Wang and Xing (2017) and Alimkhanov et al. (2021) on several vegetable crops. Osman et al. (2010) found that bio-NPK fertilizer treatments soil applied significantly increased all leaf amino acid content and mineral composition, shoot nitrogen and total carbohydrates of Manzanillo young olive trees during the two seasons.

\section{Leaf nutrient contents}

Leaf nutrient contents such as $\mathrm{N}, \mathrm{P}, \mathrm{K}$ and Mg of young Frantoio olive tree differed significantly due to different fertilization all season (Table 4). At all seasons, fertilizer treatments significantly influenced leaf nitrogen, phosphorus, potassium and magnesium content of young Frantoio olive tree compared to control treatments. In addition, it was determined that planting density affected leaf nutrient contents of olive tree at all season and fertilization types compared to control treatments, and also plant density 2 ( $4 \mathrm{~m} \times 2 \mathrm{~m}$ ) treatments resulted in the highest leaf nutrient contents in all seasons and fertilization types. Numerous studies have reported that inorganic NPK fertilizer increased growth in some species by enhancing nitrogen, phosphorus, potassium and magnesium uptake (Shehu, 2014; Gülser et al., 2019; Alimkhanov et al., 2021).

Leaf $\mathrm{N}$ concentration was significantly affected by fertilization. Maximum $\mathrm{N}$ concentration in the leaves was observed for NA followed by $\mathrm{BH}$ at all season (Table 4). Only $\mathrm{BH}$ and NA treatments, The leaf $\mathrm{N}$ concentration of the cultivars was well above the critical N level (1.5\%) in all seasons. Studies in Greece and Portugal showed that leaf $\mathrm{N}$ concentrations of various olive varieties were above the critical level (i.e., 1.84$2.15 \%$ ) (Dimassi et al., 1999; Jordao et al., 1999). However, Loupassaki et al. (2002) have reported comparatively higher values for leaf $\mathrm{N}$ concentration with a range of $1.68-2.89 \%$. The phosphorus levels of the leaves in second and third years were above the optimum level (1.0\%), but in control treatment in first season (2019) was close to the deficiency threshold level of leaf $P$ concentration (Table 4). Leaf $P$ concentration of Greek olives was in the range of 1.3-1.6\% (Dimassi et al., 1999) while it was 1.2-1.9\% in 
Portugal (Jordao et al., 1999). In contrast, Loupassaki et al. (2002) have reported a much higher range of $\mathrm{P}$ concentrations (1.7-2.7\%) for mature leaves. The potassium concentration of the leaves significantly changed as a fertilization and and years (Table 4). Maximum $\mathrm{K}$ content in the leaves was observed for NA followed by BH at all season (Table 4). Leaf content of $\mathrm{K}$ was increased in the second and third seasons than in the first season. $0.5-0.9$ and $0.54-0.83 \%$ leaf $\mathrm{K}$ concentration were reported for Greece (Dimassi et al., 1999) and Portugual (Jordao et al., 1999), respectively. In this study, the K concentrations measured were comparatively higher due to the high exchangeable $\mathrm{K}$ content of the experimental soil (380 mg kg-1). Magnesium concentration of the leaves was significantly influenced by fertilizer type and season (Table 4). Minimum values were observed for control treatments (CO) at all seasons. Loupassaki et al. (2002), Dimassi et al. (1999) and Jordao et al. (1999) have all reported that leaf Mg concentration of Greek and Portuguese olives were above $0.1 \%$, which are highly similar to our data. Seasonal change of $\mathrm{Mg}$ concentration of olive leaves was reported to be in the range of $0.1-0.2 \%$ (Christos et al., 2005).

Table 4. Effect of different types of fertilizers on leaf nutrient contents of young Frantoio olive tree

\begin{tabular}{|c|c|c|c|c|c|c|c|c|c|c|c|c|c|c|c|c|}
\hline \multirow{2}{*}{ Treatments } & \multicolumn{4}{|c|}{$\mathrm{N}, \%$} & \multicolumn{4}{|c|}{$\mathrm{P}, \%$} & \multicolumn{4}{|c|}{$\mathbf{K}, \%$} & \multicolumn{4}{|c|}{$\mathrm{Mg}, \%$} \\
\hline & 2019 & 2020 & 2021 & mean & 2019 & 2020 & 2021 & mean & 2019 & 2020 & 2021 & mean & 2019 & 2020 & 2021 & mean \\
\hline C01 & 0,7 & 0,8 & 1,2 & 0,9 & 0,5 & 1,4 & 2,0 & 1,3 & 0,7 & 0,9 & 1,6 & 1,1 & 0,4 & 0,6 & 0,9 & 0,6 \\
\hline $\mathrm{CO} 2$ & 0,9 & 1,4 & 1,8 & 1,4 & 0,8 & 1,7 & 2,5 & 1,7 & 0,8 & 1,1 & 1,8 & 1,2 & 0,5 & 0,7 & 1,0 & 0,7 \\
\hline $\mathrm{CO3}$ & 0,8 & 1,2 & 1,7 & 1,2 & 0,6 & 1,5 & 2,1 & 1,4 & 0,6 & 1,0 & 1,7 & 1,1 & 0,4 & 0,5 & 1,0 & 0,6 \\
\hline BH1 & 1,4 & 1,8 & 3,0 & 2,1 & 1,6 & 2,4 & 3,2 & 2,4 & 2,2 & 2,6 & 3,0 & 2,6 & 2,3 & 2,6 & 3,1 & 2,7 \\
\hline BH2 & 1,8 & 2,4 & 3,3 & 2,5 & 1,9 & 2,8 & 3,6 & 2,8 & 2,3 & 2,8 & 3,2 & 2,8 & 2,5 & 2,9 & 3,5 & 3,0 \\
\hline ВH3 & 1,6 & 2,2 & 3,2 & 2,3 & 1,7 & 2,7 & 3,5 & 2,6 & 2,1 & 2,7 & 3,0 & 2,6 & 2,4 & 2,6 & 3,2 & 2,7 \\
\hline CH1 & 0,8 & 0,9 & 2,4 & 1,4 & 0,9 & 2,0 & 2,5 & 1,8 & 1,2 & 1,8 & 2,5 & 1,8 & 0,9 & 1,4 & 2,4 & 1,6 \\
\hline CH2 & 1,2 & 1,5 & 2,6 & 1,8 & 1,4 & 2,1 & 2,7 & 2,1 & 1,5 & 1,9 & 2,7 & 2,0 & 1,2 & 1,6 & 2,6 & 1,8 \\
\hline CH3 & 1,0 & 1,2 & 2,5 & 1,6 & 1,2 & 2,0 & 2,6 & 1,9 & 1,4 & 1,8 & 2,6 & 1,9 & 1,1 & 1,3 & 2,5 & 1,6 \\
\hline PH1 & 0,9 & 1,4 & 2,0 & 1,4 & 0,8 & 1,7 & 2,4 & 1,6 & 1,1 & 1,7 & 2,4 & 1,7 & 0,8 & 1,1 & 2,0 & 1,3 \\
\hline PH2 & 1,1 & 1,6 & 2,3 & 1,7 & 0,9 & 1,9 & 2,6 & 1,8 & 1,3 & 1,8 & 2,5 & 1,9 & 0,9 & 1,5 & 2,2 & 1,5 \\
\hline РH3 & 1,0 & 1,3 & 2,1 & 1,5 & 0,7 & 1,8 & 2,5 & 1,7 & 1,2 & 1,7 & 2,3 & 1,7 & 0,8 & 1,2 & 2,1 & 1,4 \\
\hline NA1 & 1,5 & 1,9 & 3,2 & 2,2 & 1,5 & 2,3 & 3,0 & 2,3 & 2,4 & 2,8 & 3,3 & 2,8 & 1,9 & 2,0 & 2,3 & 2,1 \\
\hline NA2 & 1,6 & 2,5 & 3,6 & 2,6 & 1,8 & 2,4 & 3,2 & 2,5 & 2,8 & 2,9 & 3,5 & 3,1 & 2,3 & 2,2 & 2,5 & 2,3 \\
\hline NA3 & 1,7 & 2,7 & 3,5 & 2,6 & 1,7 & 2,2 & 3,1 & 2,3 & 2,6 & 2,7 & 3,2 & 2,8 & 2,2 & 2,1 & 2,3 & 2,2 \\
\hline Mean & 1,2 & 1,7 & 2,6 & 1,8 & 1,2 & 2,1 & 2,8 & 2,0 & 1,6 & 2,0 & 2,6 & 2,1 & 1,4 & 1,6 & 2,2 & 1,7 \\
\hline
\end{tabular}

It can be concluded that nutrient uptake ability and usage efficiency of young Frantoio olive trees are different fertilization. Better yield performance, along with the nutrient uptake, could be an indication of adaptation of young Frantoio olive tree to a specific ecological environment and growing conditions. Leaf nutrient contents of young Frantoio olive trees in "on" years is usually increased significantly. In conclusion, the obtained data revealed that, all fertilizers as well as the combination between 20.20 .20 (3 kg/ton water in week) and BH treatment (3kg /ton water in week) or NA treatment (2 lt /ton water in week) significantly increased morphological plant parameters (the number of leaves per shoot, stem length and stem thickness) and nutrient contents (N, P, K and Mg) of young Frantoio olive trees.

\section{References}

Alimkhanov, Y., Yeleshev, R., Yertayeva, B., Aitbayeva, A., 2021. Responses of potato (Solanum tuberosum L.) varieties to NPK fertilization on tuber yield in the Southeast of Kazakhstan. Eurasian Journal of Soil Science 10(4): 285 - 289.

Arenas-Castro, S., Gonçalves, J.F., Moreno, M., Villar, R., 2020. Projected climate changes are expected to decrease the suitability and production of olive varieties in southern Spain. Science of The Total Environment 709: 136161.

Beketova, A.K., Kaldybaev, S., Yertayeva, Z., 2017. Changes in the composition and properties of meadow solonchaks of the ili alatau foothill plain in the republic of Kazakhstan during a long postmeliorative period. OnLine Journal of Biological Sciences 17(4): 290-298.

Bilalis, D., Krokida, M., Roussis, I., Papastylianou, P., Travlos, I., Cheimona, N., Dede, A., 2018. Effects of organic and inorganic fertilization on yield and quality of processing tomato (Lycopersicon esculentum Mill.). Folia Horticulturae 30(2): 321-332.

Christos, A.C., Ioannis, N.T., Athanassios, N.M., 2005. Seasonal variation of nutritional status of olive plants as affected by boron concentration in nutrient solution. Journal of Plant Nutrition 28: 309-321.

Connor, D.J., 2005. Adaptation of olive (Olea europaea L.) to water-limited environments. Australian Journal of Agricultural Research 56(11): 1181-1189.

Dimassi, K., Therios, I., Passalis, A., 1999. Genotypic effect on leaf mineral levels of 17 olive cultivars grown in Greece. Acta Horticulturae 474: 345-348.

Fernández J.E., Moreno, F., 1999. Water use by the olive tree. Journal of Crop Production 2(2):101-162.

Fraga, H., Moriondo, M., Leolini, L., Santos, J.A. 2021. Mediterranean olive orchards under climate change: A review of future impacts and adaptation strategies. Agronomy 11(1): 56.

Gucci, R., Lodolini, E.M., Rapoport, H.F., 2009. Water deficit-induced changes in mesocarp cellular processes and the relationship between mesocarp and endocarp during olive fruit development. Tree Physiology 29(12):15751585. 
Gülser, C., Zharlygasov, Z., Kızılkaya, R., Kalimov, N., Akça, I., Zharlygasov, Z., 2019. The effect of NPK foliar fertilization on yield and macronutrient content of grain in wheat under Kostanai-Kazakhstan conditions. Eurasian Journal of Soil Science 8(3): 275-281.

Jalankuzov, T., Suleimenov, B., Busscher, W.J., Stone, K.C., Bauer, P.J., 2013. Irrigated cotton grown on sierozem soils in South Kazakhstan. Communications in Soil Science and Plant Analysis 44(22): 3391-3399.

Jones, J.B., 2001. Laboratory guide for conducting soil tests and plant analyses. CRC Press, New York, USA. 363p.

Jordao, P.V., Marcelo, M.E., Centeno, M.S.L., 1999. Effect of cultivar on leaf-mineral composition of olive tree. Acta Horticulturae 474: 349-352.

Langgut, D., Cheddadi, R., Carrión, J.S., Cavanagh, M., Colombaroli, D., Eastwood, W.J., Greenberg, R., Litt, T., Mercuri, A.M., Miebach, A., Roberts, C.N., Woldring, H., Woodbridge, J., 2019. The origin and spread of olive cultivation in the Mediterranean Basin: The fossil pollen evidence. The Holocene 29: 902-922.

Liu, Q., Lan, Y., Tan, F., Tu, Y., Sun, Y., Yougu, G., Yang, Z., Ding, C., Li, T., 2019. Drip Irrigation Elevated Olive Produ ctivity in Southwest China. HortTechnology 29(2): 122-127.

Loupassaki, M.H., Chartzoulakis, K.S., Digalaki, N.B., Androulakis, I., 2002. Effects of salt stress on concentration of nitrogen, phosphorus, potassium, calcium, magnesium, and sodium in leaves, shoots, and roots of six olive cultivars. Journal of Plant Nutrition 25: 2457-2482.

Masmoudi-Charfi, C., Mechlia, N.B., 2008. Changes in olive tree height growth during the first years of cultivation. Advances in Horticultural Science 22(1): 8-12.

Osman, S.M., 2010. Effect of mineral, bio-NPK soil application of young olive trees and foliar fertilization on leaf and shoot chemical composition. Research Journal of Agriculture and Biological Sciences 6(3): 311-318

Proietti, P., Antognozzi, E., 1996. Effect of irrigation on fruit quality of table olives (Olea europaea), cultivar 'Ascolana tenera'. New Zealand Journal of Crop and Horticultural Science 24:175-181.

Sanz-Cortes, F., Martınez-Calvo, J., Badenes, M.L., Bleiholder, H., Hack, H., Llacer, G., Meier, U., 2015. Phenological growth stages of olive trees (Olea euro-paea). Annals of Applied Biology 140:151-157.

Saparov, A., 2014. Soil resources of the Republic of Kazakhstan: Current status, problems and solutions. In: Novel measurement and assessment tools for monitoring and management of land and water resources in agricultural landscapes of Central Asia. Mueller, L., Saparov, A., Lischeid, G. (Eds.). Environmental Science and Engineering. Springer, Cham. pp. 61-73.

Shehu, H.E., 2014. Uptake and agronomic efficiencies of nitrogen, phosphorus and potassium in sesame (Sesamum indicum L.). American Journal of Plant Nutrition and Fertilization Technology 4: 41-56.

Shokparova, D.K., Issanova, G.T., 2013. Degradation of sierozem soils in the Ile Alatau Foothils. World Applied Sciences Journal 26(7): 979-986

Sofo, A., Manfreda, S., Fiorentino, M., Dichio, B., Xiloyannis, C., 2008. The olive tree: A paradigm for drought tolerance in Mediterranean climates. Hydrology and Earth System Sciences 4: 2811-2835.

USDA, 1999. Soil Taxonomy. A Basic System of Soil Classification for Making and Interpreting Soil Surveys. United States Department of Agriculture, Natural Resources Conservation Service, Agriculture Handbook Number 436. 886p. Available at [access date:21.05.2021]: https://www.nrcs.usda.gov/Internet/FSE_DOCUMENTS/nrcs142p2_051232.pdf

Wang, X., Xing, Y., 2017. Evaluation of the effects of irrigation and fertilization on tomato fruit yield and quality: a principal component analysis. Scientific Reports 7, 350.

Yertayeva, Z., Kaldybaev, S., Beketova, A., 2018. The scientific basis of changes in the composition and properties of meadow saline soil of the foothill plains of the ili alatau during a long postmeliorative period. Ecology, Environment and Conservation 24(2): 715-720. 